In 1 edia $\quad \begin{aligned} & \text { InMedia } \\ & \text { The French Journal of Media Studies }\end{aligned}$

8.2. $\mid 2020$

What do Pictures Do? (In)visibilizing the Subaltern

\title{
Performance and Identity in Adrian Piper's Work
}

\section{Antonia Rigaud}

\section{(2) OpenEdition}

\section{Journals}

Electronic version

URL: https://journals.openedition.org/inmedia/2754

DOI: 10.4000/inmedia.2754

ISSN: 2259-4728

\section{Publisher}

Center for Research on the English-Speaking World (CREW)

\section{Electronic reference}

Antonia Rigaud, "Performance and Identity in Adrian Piper's Work", InMedia [Online], 8.2. | 2020, Online since 22 October 2021, connection on 28 October 2021. URL: http://journals.openedition.org/inmedia/ 2754 ; DOI: https://doi.org/10.4000/inmedia.2754

This text was automatically generated on 28 October 2021.

(c) InMedia 


\title{
Performance and Identity in Adrian Piper's Work
}

\author{
Antonia Rigaud
}

\section{Introduction}

1 Adrian Piper's 1988 video installation Cornered ${ }^{1}$ consists of a single shot of the artist looking straight into the camera, addressing her viewers with a reflection on her identity. Her opening words - "I am Black"- are a statement of racial identity that, Piper suggests, might "disturb [the viewer's] presumption that [she is] white". The piece is interested in a theoretical and moral reflection on racial identity and the racist assumptions that make us define the identity of others based on superficial perceptions and archetypal visions of, in this instance, what it is to be Black or to be White. She explains this in an interview with Maurice Berger:

We need to understand how these deeply buried archetypes function in our character and personalities, how they engender a sense of security when people look and act as they are 'supposed to' and fear and anger when they don't. These perceptual issues are fundamental. ${ }^{2}$

Piper questions "perceptual issues" by unsettling our "sense of security" and of identity as a fixed reality. The video's theme is an old one in African American culture: Wallace Thurmond's classic 1929 Harlem Renaissance novel, The Blacker the Berry considers the social problems confronting the protagonist, Emma Lou Morgan, who is born "too black" for a certain Black middle class coming to the fore in the era after World War I, which fetishizes lighter skin. Piper's video installs a dialogue between the artist and her audience in a context of assumptions about skin and personhood which centers around the question of how someone's skin-color identity is constructed, suggesting that identity is not necessarily a given but, instead, the product of expectations in which racism and what Piper calls "perceptual issues" are intertwined. As Thurman's heroine reflects at the beginning of the novel:

Everything possible had been done to alleviate the unhappy condition, every suggested agent had been employed, but her skin, despite bleachings, scourgings, 
and powderings, had remained black -fast black- as nature had planned and effected. ${ }^{3}$ the American social order despite the distance in time between the story of Emma Lou, Adrian Piper's 1988 Cornered and her artworks today. The advances of the Civil Rights era notwithstanding, Piper's reflections on race and "perceptual issues" bear on a reality at the heart of the American experience throughout history. Her reflections are also those of an artist who is a professional philosopher, a former student of John Rawls, she is concerned with issues of ethics and politics in an analytical vein, influenced by her reading of Kant. ${ }^{4}$ her themes that allows us to relate Cornered to a piece made twenty-four years later, where the artist announced: "Adrian Piper has decided to retire from being black." This 2012 statement encompasses questions that I see as central to her art practice since the 1960s. A conceptual artist strongly influenced by Sol LeWitt, one of the most prominent conceptual and minimalist artists when she began her career, Piper turned to performance art in the late 1960s, interrogating social and racist constructs through her character "Mythic Being", the artist's male alter ego which appeared in newspaper ads, photographs and performances in the streets of New York. ${ }^{6}$ Retiring "from being black" is a distinctly ambiguous, if not absurd, statement which illustrates what I believe is an open ambivalence at the heart of her explorations of identity. Her resignation is given meaning by the use of the word "retire", in its implication that racial identity is an occupation. We must consider this resignation in the light of a career spent exploring the violence of deeply engrained racism in American society. She is reclaiming agency in refusing to accept race as a given. Retiring "from being black" reads as claiming her own identity, on her own terms. And yet, this emphasis on individual choice is, as Piper knows well, exactly the move that a racist society blocks. To "retire" from being black implies that Piper, at some point, chose to be Black, as a person chooses to be an artist, or a philosopher.

While we cannot say that Piper's 2012 announcement "Adrian Piper has decided to retire from being black" referenced her statement from 1987 "I am black," we can say that the latter affirmation puts into question the meaning of Cornered as an identity claim. In moving from the first to the third person of the singular, these two statements also seem to suggest a gradual detachment from the self as an object of study, not through the prism of autobiography, but rather as a study of the possibilities and limits inscribed in being of " $1 / 16^{\text {th }}$ African heritage" 7 in a country where racism shapes racial and social positions. Piper's first artworks in the 1960 s were very clearly part of the conceptual art movement but the political tensions and violence of the 1970s led her to change her perspective and to open up her conceptual art practice to identity questions. In this respect, her career in the seventies tracks and combines the conceptualist aesthetic usually associated with White artists and the rise of identity art as represented by the rise of feminist performance and identity-based artistic explorations.

6 Piper was celebrated by the Museum of Modern Art in New York in 2018 in a major retrospective entitled Adrian Piper: A Synthesis of Intuitions, 1965-2016, providing a wide view of her career as an artist - even though she was in the rare position of being, at the same time, a tenured philosophy professor. Piper did not attend the show as she 
left the United States in 2005 for Berlin, vowing not to return to the country until her "constitutional rights are fully restored," ${ }^{8}$ notably due to the fact that she had discovered she was on the Suspicious Traveler watchlist of the U.S. Transportation Security Administration. Piper, whose performances play on the uncertain dichotomy between the visible and the invisible, between the given and the fact that we cannot really know the given, was the invisible presence in one of the most visited and talked about shows that MoMA has ever mounted. The paradox of such a major moment in the artworld and the absence of the show's celebrated artist is very much in the image of Adrian Piper's career: I would argue that her exemplary contribution to the artworld has been to bring together the conceptualist obsession with what is visible and what is not, and the performative insight that identities are performed and not given. Hers is an art marked by in-your-face presentations of herself as well as withdrawals and retirements which leave the spectator and the critic the task of teasing out the aesthetic logic-as well as the implicit ethical summons to examine the systems of identity which structure our ordinary lives.

7 In her "Notes on Mythic Being I-III", Piper puts forward a difference between the self and the performing self. She writes:

I began by dressing in the guise of the Mythic Being and appearing publicly several times during the month (reascription of my thoughts and history, sentence by sentence, to a masculine version of myself; myself in drag). I now consider shelving this aspect of the piece for fear that the Mythic Being will gradually acquire a personal autobiography of experiences and feelings as particular and localizedand limited-as my own. This was the misfortune of Rrose Selavy [sic] ${ }^{9}$.

8 The reference to Marcel Duchamp's alter ego Rrose Sélavy, helps to situate her work within the tradition of avant-garde American art which has been traversed by a number of personas, from Duchamp to Cindy Sherman, questioning the validity of fixed identities. ${ }^{10}$ Disguises call for an examination of what is made visible and what is hidden in representations of the self. Piper draws from two apparently opposed trends in recent American art: conceptualism and identity performance art. Piper's art oscillates between extreme visibility and disappearance, both construed as strategies to exist as an African-American female artist in the New York artworld. These strategies all rest on the idea that the artwork should lead to a questioning of the conditions in which our social relations exist, in reality as well as in the art world, in order to give us the possibility to renew and keep alive difference within a social order founded on freedom and equality.

\section{"I Embody Everything You Most Hate and Fear":11 Giving Visibility to the Subaltern}

9 Adrian Piper's biography can be considered as a synthesis of two strong currents in the postmodern art scene: the turn to performance within a conceptualist dominated New York artworld and the turn to theory, which in her case resulted in her career as a tenured philosophy professor at Wellesley College. Adrian Piper's privileged position, seen from this perspective, does not seem to belong to the category of the "subaltern," in as much as the term is usually applied to figures on the periphery. While Piper's work has been supported by culturally-powerful institutions, this does not contradict the fact that racist suppositions and segregation pervade the artworld even as it aspires to be a completely emancipatory space. Gayatri Spivak's famous question "Can the 
Subaltern Speak?" raises the question of the possibility for the subaltern to be able to express himself/herself outside of the vocabulary of the powerful and intellectuals. Piper's reference to her "Mythic Being" as "third world,"12 has an affinity with Spivak's question, in that it evokes the late 1960s anticolonial struggles for recognition and independence.

She explores this problem in her work, notably in the video piece Cornered which seems directly drawn from her biography as it includes her father's two birth certificates pinned to the sides of the video monitor - one where he is identified as "white" and the second where he is identified as "octoroon". In the video, the artist addresses her audience in the following words: "But you see, I have no choice. I'm cornered. If I tell you who I am, you become nervous and uncomfortable, or antagonized. But if I don't tell you who I am, then I have to pass for white ${ }^{13}$." The latter is not an exaggeration, as Piper has detailed in her 1991 essay, "Passing for White, Passing for Black." The artist presents her identity as a continual negotiation with other people's assumptions, which are organized through the prevalence of a certain racist heuristic: her identity lies unsteadily in the middle between either being a member of a minority group or being inauthentic. In explaining that she has no choice, she removes the codification of race from its seemingly-natural foundations and points towards the contingency of racial differentiation. She explains:

But I've learned that there is no "right" way of managing the issue of my racial identity, no way that will not offend or alienate someone, because my designated racial identity itself exposes the very concept of racial classification as the offensive and irrational instrument of racism it is. ${ }^{14}$

11 Giving visibility to herself as a minority member, as she does in Cornered for example, is not only an aesthetic investigation but a political gesture, illuminating the question of her own identity and the identities of others. This can be interpreted as sheer provocation as she explains about a viewer's reaction to one of her shows: "recently I premiered at a gallery a video installation exploring the issue of African ancestry among white Americans. A white male viewer commenced to kick the furniture, mutter audibly that he was white and was going to stay that way, and start a fistfight with my dealer." ${ }^{15}$ In a sense, the White male viewer was responding to an ontological provocation, since the ground of his identity as he understood it was being questioned. To point out that identity is in flux in a society with such seemingly rigid racial codes destabilizes assumptions about fixed racial categories. Piper's work seems to examine the notion of the "color line" defined by W. E. B. Du Bois in his seminal text from 1909, The Souls of Black Folk, by showing how fleeting and uncertain the very idea of a color line is, thus debunking this American racist code. Du Bois explains the color line as being all the more rigidly applied in the United States as it is grounded in ambiguous and fleeting realities. Piper's work seems to take up these themes and even reference the ambiguity of heredity as a racial definer, as Cornered suggests.

Her work unfolds as a career-long answer to the question with which $\mathrm{Du}$ Bois opens his essay:

Between me and the other world there is ever an unasked question: unasked by some through feelings of delicacy; by others through the difficulty of rightly framing it. All, nevertheless, flutter round it. They approach me in a half-hesitant sort of way, eye me curiously or compassionately, and then, instead of saying directly, How does it feel to be a problem? they say, I know an excellent colored man in my town; or, I fought at Mechanicsville; or, Do not these Southern outrages make your blood boil? At these I smile, or am interested, or reduce the boiling to a 
simmer, as the occasion may require. To the real question, How does it feel to be a problem? I answer seldom a word. ${ }^{16}$ subaltern at the heart of the art conversation. Performances, photographs, placards and videos are the main media she uses in order to give life to an artistic persona, the "Mythic Being". Piper's "Notes on the Mythic Being" which she published as part of the piece show her contemplating what it means to be in drag as an African American man (she called it "a masculine version of [her]self"18). With an Afro wig and mustache, Piper, dressed as a man, roams the streets of New York, performing an aggressive form of masculinity; one of the performances was entitled "The Mythic Being Cruising White Women" showing how Piper sought to shock and confront her audience (which, due to the real-world staging of her performance, was unaware of the performance as an "act"). John P. Bowles refers to this performance as a "self-conscious performance of stereotypes," ${ }^{19}$ underlining the artist's interest in debunking our established categories. The visuals of the photographs from the series borrow from comic book aesthetics, the person who the artist disguises herself as is accompanied by bubbles where the viewer can read the "Mythic Being"'s thoughts. The artist published ads for the "Mythic Being" in newspapers such as the Village Voice, thus opening her performances to different everyday life situations, or at least the everyday life of the audience that the Village Voice addressed, a largely White, urban, and educated one. She gives agency to a "Mythic Being," in other words to a subject who has no existence in reality, yet who is given substance and corporeality by being perceived through certain simple properties: facial hair shaped a certain way, sunglasses, an Afro wig. These properties have been associated to racist and gender stereotypes, as suggested by John P. Bowles. The name "Mythic Being" encapsulates the way Piper thinks about vision and identity: it seems to suggest that being is always connected to mythmaking, or narrative rather than to the synthetic a priori of reality, which is existentially inaccessible to immediate knowledge. She takes identity as provocation instead of definition and the "Mythic Being" allows her therefore both to question our stereotypes and to suggest that final definitions of the self are closer to myth than the changing movements of reality. bubble reading "I embody everything you most hate and fear." ${ }^{20}$ The affirmation seems both to be a statement of fact and an expression of defiance; it calls on a definition of the self as necessarily in relation to the other: the corporeal identity ("I embody") does not exist in and of itself but in relation to another. The "you" here has been identified, by reviewers hostile to Piper's work, as the typical "white liberal" art gallery goer. ${ }^{21}$ But Piper does not make any such suggestion, in fact the "you" could well be a black spectator and the "mythic being" might be identified by the spectators as Black only through his props which activate racist stereotyping. The identity of the self is here defined in flat opposition to the other, suggesting a logic of oppositions - love versus hate, stability versus fear. These oppositions take on a political dimension, something 
which the artist analyzes in another performance entitled Some Reflective Surfaces (1975):

Voluntary self-objectification, of the kind that occurs in dancing, in performance of any kind, in modeling, or in permitting oneself to be looked at or done to sexually can be an act of political defiance, a gesture of brazen shamelessness, a celebration of self that absolutely crushes and makes ridiculous any attempt at devaluation or disapproval. ${ }^{22}$

The artist plays with the idea of objectification which she turns around through what she calls "voluntary self-objectification" in order to suggest that the fact of giving visibility to the self is akin to giving agency to oneself. While exploring the self's variability, she creates ambiguity and thus remains in control of her portraits which, she hopes, should be seen as celebrations of the self rather than being met with disapproval. Giving visibility to the self is here presented as an act of radical exploration of the self's variability. The artist's body is the medium of most of her artworks as well as its subject matter. She explained in 1998, "Basically I treated my physical form as a sculptural object and manipulated it in all sorts of ways with respect to shape and smell and texture." ${ }^{23}$ The artist's body becomes a visual puzzle, a sort of problem the answer to which is held by the artist in dialogue with her audience. Her identity as well as that of the audience is called into question so that the self - that of the artist, that of the audience members - is in the process of becoming, rather than having an essential definition.

In Scenes of Subjection: Terror, Slavery and Self-making in Nineteen-century America, Saidiya Hartman has shown the importance of visibility for the African American subject in American literature and culture, calling attention to the racist tendency to give hypervisibility to the African American body as victim of extreme physical violence. In this context, visibility is not necessarily a goal for the artist but a potential trap which Piper must and does thwart through the strategy of direct address. She plays with the possibilities of being seen or not seen, which we can call a strategy of disguise. In disguising oneself, the performer withholds some information about herself from those she encounters. It is a strategy that by its very nature plays on a certain hypothesis that people react according to stereotypes of race and gender through which they perceive people they encounter. Yet the performance does not give full agency to the viewer in making meaning of what he or she sees, it is rather the subject presenting herself to others and her decision about what will be seen. She cannot, however, dictate anything (she explains "I do not want to "make people behave better"" ${ }^{24}$ ), but she does create a space for encounter between artist and viewers. Visibility is therefore not to be understood as part of an educational or didactic artistic gesture, but rather as the opening up of a discussion on visibility, on what it means and how it engages both the self and the viewer. However, visibility is only one strategy, which is counterbalanced by the reverse strategy of disappearance, playing with the codes of visibility and invisibility.

\section{"Retiring from Being Black": The Strategy of Retreat}

Piper announced her retirement from "being black" in Thwarted Projects, Dashed Hopes, A Moment of Embarrassment (2012). The piece is a photograph of the artist smiling. Her visible skin-neck, face, and ears-are covered in blackface makeup. It conceals her lips and extends to the roots of her hair. The transformation of her skin color is made very 
visible, calling the viewer's attention to the changes made to her skin. The contrast between the photograph and the caption that accompanies it is particularly striking. The text concludes with this statement, "Please join me in celebrating this exciting new adventure in pointless administrative precision and futile institutional control!", commenting on the gap between administrative rhetoric and the reality of racism. She explained: "For professional utility, you may wish to refer to her as The Artist Formerly Known as African-American." ${ }^{25}$ Piper here seems to suggest a desire to go back to a universalist definition of the artist, one that she started her career with when she was "drunk on abstract conceptual metaphysics." ${ }^{26}$ Yet she does not choose to go back to an art practice focused on form in order to leave identity questions behind her. She remains concerned with interrogating identity but refuses to treat it as simple and straightforward. The retreat uses the full force of irony, it seems to want to create a closing moment over a career-wide thematic but at the same time puts into question identity claims that had in fact been the content of her work from the beginning. This retreat from "being black" is probably to be understood as a withdrawal from straightforward and final definitions of the self. John P. Bowles has explained: "Piper simultaneously lays claim to universality while critiquing and historicizing its traditionally imperfect application." ${ }^{27}$ Her work seems to rest on aporia: it is about identity as self-creation while denying that the self can exist as an autonomous entity since the work is about the necessary relations between artist and viewers.

It is very striking, when looking at Piper's 60-year career, to see that, despite being extremely concerned with a sort of in-your-face visibility, it is marked by a great number of moments of retreat, disappearance and invisibility. The scope of Adrian Piper's career can be understood as following a series of withdrawals, of disengagements with the institutions of art and education. In Escape to Berlin, a Travel Memoir published in 2018 in a bilingual English and German edition by APRA Foundation Berlin, her research foundation established in the German capital, she recounts her departure from the United States. The book opens on this central question: "Would you like to know why I left the U.S. and refuse to return? This is why." ${ }^{28}$ The memoir documents the reasons for her chosen exile, exploring the passage in her life from the sheltered childhood of an only-child in a middle-class intellectuallyoriented family to her career as a conceptual artist, as a philosopher and to her exile in Germany.

Piper practices institutional critique as an artist and an academic: her biography can be read as a weave of engagements and disengagements. Her double career as an artist and a philosopher has been spent in the museums and galleries that sponsored her artistic work as well as the universities in which she has taught, but she has advanced in both of these careers with profound skepticism about these institutions as loci of power, conscious of their ability to stop listening to her voice. This motif of disengagement can be seen as a double defense of her autonomy, first as a person, and then as an African American woman with pale skin. She has been engaged in themes that have a long life in America's dissident culture, starting with Emerson's concept of "self-reliance", the locus classicus of the American ideology of the self as autonomous and resistant. Piper can be situated within this culture of dissent which has countered the mixture of ideological individualism and real conformism, of appeals to equality and real oppression, by registering its failures, and by trying to make the self the site of a continual experiment. 

in her writings, but she has transformed this early rejection into a way of retreating on her own terms. She describes herself as a young artist as mostly "perched on the outer edge of the art world." ${ }^{29}$ This forced marginal position is something she has consciously sought, and it is a recurring motif throughout her career, starting in 1970 when she withdrew a piece meant for the "Conceptual arts and conceptual aspects" at the New York Cultural Center. She replaced the piece with the following note: "The work originally intended for this space has been withdrawn.... I submit its absence as evidence of the inability of art expression to have meaningful existence under conditions other than those of peace, equality, truth, trust, and freedom." ${ }^{30}$ The statement illustrates the impact of the political context on her work and vision of herself as an artist ${ }^{31}$, yet it raises the question of the validity of art if art needs the conditions "of peace, equality, truth, trust, and freedom" in order to have meaning. The statement is also paradoxical in that she stages her absence as an actual presence. She constructs an exchange between the invisibility of the work and the visibility of the marker that points to this very invisibility. This doubleness creates a sense of irony, opening a space between literal meaning and endless possibilities of signification.

In 2013, she withdrew a video of the Mythic Being series from the exhibition Radical Presence: Black Performance in Contemporary Art at New York University's Grey Gallery as she refuses to have her work included in what she calls "racially segregated exhibitions." ${ }^{32}$ While the institutional critique of art as art has emerged as a theme in post-conceptual art with artists such as Hans Haacke, Piper shines a light on a topic that has concerned almost all major African-American artists of the $20^{\text {th }}$ and $21^{\text {st }}$ centuries who have had to deal with the highly segregated world of art. Her art here is in continuity with her art-criticism-expressed in the anthology Institutional Critique: An Anthology of Artists' Writings edited by Alexander Alberro and Blake Stimson, where Piper published two early 1980s essays: "Some Thought on the Political Character of This Situation" and "Power Relations within Existing Art Institutions." Both essays give her the opportunity to explain how she seeks to bring together conceptual art and politics:

My interest is to fully politicize the existing art-world context to confront you here with the presence of certain representative individuals who are alien and unfamiliar to that context in its current form, and to confront you with your defense mechanisms against them. ${ }^{33}$

Conceptualism allowed Piper to situate her art within abstract reflections, detached from social constraints, yet it is precisely through abstraction that she reached the body which in turn led her to a more socially-conscious artform.

In the performance entitled Calling Cards, where she distributes calling cards to the people she encounters randomly, Piper interrogates the social dimension of visibility. She plays on the social tradition of the calling card to interrogate the workings of social relations. Jacqueline Royster analyzes this tradition in the introduction to Calling Cards: Theory and Practice in the Study of Race, Gender and Culture:

In the nineteenth century in both Europe and the United States, there was a firmly established and highly developed social ritual of presenting oneself to others within elite social circles by means of a small, often elegantly decorated, card. Calling cards, as they came to be called, became a primary instrument by which social overtures were made, invitations were extended, and social acceptance (or rejection) in these circles was negotiated..$^{34}$ 
calling cards symbolize social acceptance or rejection and thus allow Piper to reflect on the ritualization and codification of social life. Her piece can be analyzed in relation to the way $\mathrm{Du}$ Bois describes this ritual in The Souls of Black Folk, where he reflects on his dawning self-awareness as a Black boy in relation to a game of exchanging calling cards:

I remember well when the shadow swept across me. I was a little thing, away up in the hills of New England, where the dark Housatonic winds between Hoosac and Taghkanic to the sea. In a wee wooden schoolhouse, something put it into the boys' and girls' heads to buy gorgeous visiting-cards - ten cents a package - and exchange. The exchange was merry, till one girl, a tall newcomer, refused my card, - refused it peremptorily, with a glance. Then it dawned upon me with a certain suddenness that I was different from the others; or like, mayhap, in heart and life and longing, but shut out from their world by a vast veil.

With this anecdote, Du Bois shows how the ritual of exchanging cards is closely associated to the idea of belonging since his card is refused because of his skin color. It is perhaps with $\mathrm{Du}$ Bois in mind that Piper distributed cards such as the following one:

Dear Friend.

I am black.

I am sure you did not realize this when you made/laughed at/agreed with that racist remark. In the past, I have attempted to alert white people to my racial identity in advance. Unfortunately, this invariably causes them to react to me as pushy, manipulative or socially inappropriate. Therefore, my policy is to assume that white people do not make these remarks, even when they believe there are no black people present, and to distribute this card when they do.

I regret any discomfort my presence is causing you, just as I am sure you regret the discomfort your racism is causing me..$^{35}$

Here the card is not part of a social ritual but it allows the artist to engage in a monologue with her audience, playing with the motif of the traditional calling card: they are distributed for them to be read alone, rather than Piper engaging in a conversation with others. One might argue that the calling cards are a way of igniting a conversation while at the same time disengaging from it, leaving the person receiving the card unable to have a conversation and forced to think about these questions on his/her own.

Retreating from direct engagements with her audiences or with art institutions is a way of refusing a conversation that would be directed by power. Indeed, if Spivak is correct in explaining that "the 'subaltern' cannot appear without the thought of the elite" ${ }^{36}$, then we can see Piper's gesture as a way of regaining discursive power. Refusing any type of direct interaction, Piper gives herself the space to appear on her own terms, "without the thought of the elite". Piper is a sort of modern-day Bartleby who "would prefer not to", expressing a radical refusal to enter a world marked by stereotypes and biases and calling for a new world, new relationships. Her retrospective at the Museum of Modern Art ends with a video of the artist dancing with an expression of deep joy on her face. Adrian Moves to Berlin ${ }^{37}$ raises the question of whether "Adrian" is here another persona, in line with others she created and whether this dance is one of joyous liberation from the administrative constraints of the United States and its heritage of racism. 


\section{“Probable Trust": Art as Social Contract} archetype of the African-American performer in American culture. She seems to prolong Ralph Ellison's reflections in his 1958 essay "Change the Joke and Slip the Yoke" where he discussed blackface as fashioned by white culture. Piper, a lightskinned African-American performer, confronts White assumptions as an AfricanAmerican artist working in the context of the white entertainment industry which Ellison analyzes in the following terms, "[it] thrives on the exploitation and debasement of all folk materials, [where] the Negro is reduced to a negative sign that usually appears in a comedy of the grotesque and the unacceptable." ${ }^{38}$ Playing with stereotypes, or the caricature of the "Mythic Being," she refuses the racist convention of the Black performer as entertainer for Whites. Given what we know about the logic that leads from entertainment to debasement, as per Ellison's insights, we would do well to put Piper's performances in relation not only to high culture conceptual art but also to the popular culture of Black performance. Ralph Ellison analyzes the role of masks in American culture, showing how they allow both to present prejudice and to hide at the same time. He writes:

Very often, however, the Negro's masking is motivated not so much by fear as by a profound rejection of the image created to usurp his identity. Sometimes it is for the sheer joy of the joke; sometimes to challenge those who presume, across the psychological distance created by race manners, to know his identity. Nonetheless it is in the American grain..$^{39}$

Ellison's analysis of blackface in American culture allows us to see how Piper's performances belong to a tradition of hypervisibility and masks which keeps audiences from knowing and seeing others. What she ultimately gives visibility to, rather than her life or identity, is the American culture of invisibilization.

31 The performances of the "Mythic Being," which she calls "unannounced street performances" plunge the creation of the "Mythic Being" into the streets of New York, allowing him to interact with passersby. She explains, "unobtrusively insinuating art into nonart situations really interests me. I like the idea of doing away with all discrete forms, and letting art lurk in the midst of things." 40 The idea that art "lurks" in the middle of everyday life situates Piper in line with the proponents of happenings which Allan Kaprow defined as "the blurring of art and life," 41 but it also brings an element of surprise, or of danger, as if art appearing suddenly in the middle of everyday life might disrupt the status quo. Indeed, in putting at the heart of the artwork a representation of invisible populations, in giving visibility to the subaltern, Piper seeks to interrogate her viewers' assumptions and racism in order to open a discussion as to each individual's responsibility in a racist society. She asks her viewers in Cornered "What are you going to do about it?" after her initial statement "I am Black." The direct address to the viewer, this commanding question, is at the heart of her artistic project which derives from the 1960s movement towards audience participation in conceptual art, yet it diverts that formalist approach in order to implicate the viewer in questioning his or her relationship to others in society.

Her work is evocative of happenings which dominated the New York art scene in the 1960s and 1970s, but she redefines the genre, infusing it with a distinctly political and ethical dimension. When John Cage organized in 1952 at Black Mountain College what

InMedia, 8.2. | 2020 
has been considered as the first happening, which he referred to as "the event," he was inaugurating a tradition in conceptual art which sought to intensify the audience's experience of art, proposing an immediate relationship to the artwork considered first and foremost as an experience. Happenings were influenced by John Dewey's $1934 \mathrm{Art}$ as Experience as they sought "to restore continuity between the refined and intensified forms of experience that are works of art and the everyday events, doings and sufferings that are universally recognized to constitute experience." ${ }^{42}$ Dewey's pragmatist and democratic definition of art relied not on taste or categories such as the beautiful or the ugly, but on the spectator's experience and refused to accept the prescribing roles of art institutions which tend to canonize artworks, putting the notion of "experience" at the heart of any artistic event. He wrote, "But experience in its vital form is experimental, an effort to change the given; it is characterized by projection, by reaching forward into the unknown; connection with the future is its salient point." ${ }^{43}$ Piper's performances therefore seem to borrow from the formalist beginnings of happenings which later became performances, but they prolong these first happenings by situating the experience on a political and moral plane, one which seeks "to change the given," to awaken her audience to individual and systemic racism. She prolongs the avant-garde experiments with form and experience but transforms them into propositions about the state of American democracy, very much in line with Dewey's project for a "radical democracy" based on the concept of resistance which he defined in the following words:

Nor without resistance from surroundings would the self become aware of itself; it would have neither feeling nor interest, neither fear nor hope, neither disappointment nor elation. Mere opposition that completely thwarts, creates irritation and rage. But resistance that calls out thought generates curiosity and solicitous care, and, when it is overcome and utilized, eventuates in elation. ${ }^{44}$

If Piper's main focus in her art is to debunk racial and gender stereotypes, it must however be noted that what she creates is a continuous reappraisal of our relationships one with another, thus creating a democracy based on continuously redefined relationships. Piper's artworks present themselves as the place where the audience and the artist are made to negotiate their definitions of social categories and of the society they want to build for themselves. Her artworks are not objects so much as experiences, but here the experience goes further than in high conceptualist pieces promoted by the often White male New York avant-garde, it is an experience of being in relation to the Other, questioning our attitudes towards one another. She explains:

I want viewers of my work to come away from it with the understanding that racism is not an abstract, distant problem that affect all those poor, unfortunate other people out there. It begins between you and me, right here and now, in the indexical present. ${ }^{45}$

In her 2013 piece The Probable Trust Registry: The Rules of the Game \# 1-346 for which she won the Venice Biennale Golden Lion in 2015, Piper presents her art as a new social contract, the artwork consisting in an experience binding artist and audience together: the audience members are indeed invited to sign contracts accepting to follow a number of rules defined by the artist. The piece exists as a series of statements committing the person reading them, as sealed in contracts signed by the audience members. The description of the contract shows the artist's concern with art as a negotiation binding the artist and the participants, as well as the participants among themselves as the description stipulates that "Should one Signatory wish to contact another, the Contactor must contact the Gallery/Exhibiting Collector to request the 
Contactee's contact information." ${ }^{47}$ The legal dimension of the artwork which comes into being at the moment of the signing of the contract calls for a reappraisal of the relationship we engage in with art. Piper is indeed not interested in art as entertainment but rather in art as bearing on ontological and philosophical questions. The piece is performative since it comes into being each time the contract is signed and at such a time it represents an ideal society based on an autonomous and conscious awareness of others.

The three statements which the audience members are made to commit to all involve taking an oath: "I will always be too expensive to buy," "I will always mean what I say," "I will always do what I say I am going to do." They operate in a fashion very close to performatives, the signing of the contract by viewers calling on their moral responsibility to follow through with the statement. The viewer's responsibility is fully engaged, whether he or she participates or refuses to participate in the transaction, the artist does not allow her audiences to dismiss her work without being morally implicated by this refusal. At the same time however, the statements force the people signing the contract into a problematic position since these demands for life-long authenticity are very difficult, if not impossible. The work resides in the paradox of a "probable trust" between artist and viewers.

\section{Conclusion}

In the image of Cornered in which the artist looks directly out of the camera into her viewer's eyes, Piper's artistic persona creates a direct relationship as she hails her viewers and addresses them directly, keeping them from hiding from her. She imposes herself as a figure of great authority who will not tolerate any avoidance of the confrontations she stages in her performances. Her position is that of an instructor whose lessons, like her early 1980s Funk Lessons where she gave seminars in funk music and culture to a mostly White audience, seek to create understanding. The lessons she teaches us are grounded in the social contract her works call on us to renew with the artist and each other, so much so that the artist whose body and face are so central to many of her works is actually very much a disappearing artist who seems to choose invisibility as a strategy to make us confront our prejudices and blind spots.

\section{BIBLIOGRAPHY}

Alberro, Alexander and Blake Stimson eds. Institutional Critique: An Anthology of Artists' Writings. Boston, MA: MIT Press, 2009.

Berger, Maurice. “The Critique of Pure Racism: An Interview with Adrian Piper.” Afterimage 18, no. 3, 1990 .

Bowles, John P. Adrian Piper: Race, Gender, and Embodiment. Durham, NC: North Carolina University Press, 2011. 
Bowles, John P. “'Acting like a Man': Adrian Piper's Mythic Being and Black Feminism in the 1970s." Signs 32, no. 3 (Spring 2007): 621-647.

Cherix, Christophe, Connie Butler, David Platzker, and Adrian Piper. Adrian Piper: A Synthesis of Intuitions 1965-2016. New York: The Museum of Modern Art New York, 2018.

Dewey, John. Art as Experience. New York: Penguin, 2005.

Du Bois, W. E. B. The Souls of Black Folk. New York: Dover, 1994.

Ellison, Ralph Waldo. Collected Essays. John F. Callahan ed. New York: Modern Library, 2003.

Fleetwood, Nicole R. Troubling Vision: Performance, Visuality, and Blackness. Chicago: University of Chicago Press, 2011.

Hartman, Saidyia. Scenes of Subjection: Terror, Slavery, and Self-Making in Nineteenth Century America. New York: Oxford University Press, 1997.

Johnson, Ken. “Art in Review: Adrian Piper," New York Times, November 17, 2000. https:// www.nytimes.com/2000/11/17/arts/art-in-review-adrian-piper.html?searchResultPosition=1 <accessed on August 27, 2021>

Kaprow, Allan. The Blurring of Art and Life. Berkeley, CA: University of California Press, 1993.

Lippard, Lucy. Six Years: The Dematerialization of the Art Object from 1966 to 1972. New York: Praeger, 1973.

McMillan, Uri. Embodied Avatars: Genealogies of Black Feminist Art and Performance. New York: New York University Press, 2015.

Noble, Kerry and Cheryl Misak eds. Pragmatism. Calgary: University of Calgary Press, 1999.

Piper, Adrian. Escape to Berlin. Berlin: Adrian Piper Research Archive, 2018.

Piper, Adrian. Funk Lessons, Adrian Piper Research Archive. http://www.adrianpiper.com/vs/ video_fl.shtml <accessed on August 27, 2021>

Piper, Adrian. "Letter to the Editors of the New York Times," Adrian Piper Research Archive. http://www.adrianpiper.com/ny_times.shtml <accessed on August 27, 2021>

Piper, Adrian. “News,” Adrian Piper Research Archive. http://www.adrianpiper.com/ news_sep_2012.shtml <accessed on August 27, 2021>

Piper, Adrian. "Notifies Wellesley College of SSSS List and Requests Indefinite Leave of absence," Adrian Piper Research Archive. http://www.adrianpiper.com/docs/IndefLvApplic.pdf <accessed on August 27, 2021>

Piper, Adrian. Out of Order, Out of Sight. Volume 1 Selected Writings in meta-Art, 1968-1992. Cambridge, MA: MIT Press, 1999.

Piper, Adrian. Out of Order, Out of Sight. Volume 2 Selected Writings in Art Criticism 1967-1992.

Cambridge, MA: MIT Press, 1999.

Piper, Adrian. "Removed and Reconstructed en. Wikipedia Biography," Adrian Piper Research Archive. http://www.adrianpiper.com/removed-and-reconstructed-en.wikipedia-

biography.shtml <accessed on August 27, 2021>

Piper, Adrian. "The Probable Trust Registry,” The Adrian Piper Research Archive. http:// www.adrianpiper.com/art/The_Probable_Trust_Registry.shtml <accessed on August 27, 2021> 
Piper, Adrian. “TPTR Generalized Performance Instructions Website," The Adrian Piper Research Archive. http://www.adrianpiper.com/art/docs/

TPTRGeneralizedPerformanceInstructionsWebsite.pdf <accessed on August 27, 2021>

Royster, Jacqueline and Ann Marie Mann Simpkins eds. Calling Cards: Theory and Practice in the Study of Race, Gender and Culture. Albany, NY: SUNY Press, 2012.

Smith, Cherise. Enacting Others: Politics of Identity in Eleanor Antin, Nikki S. Lee, Adrian Piper, and Anna Deveare Smith. Durham, NC: Duke University Press, 2011.

Spivak, Gyatri. "Subaltern Studies: Deconstructing Historiography." In Selected Subaltern Studies, edited by Ranajit Guha and Gyatri Chakravorty Spivak, 3-32. New York: Oxford University Press, 1988.

Thurmond, Wallace. The Blacker the Berry. New York: Macaulay, 1929.

Yancy, George ed. African-American Philosophers New York and London: Routledge, 1998.

Zabunyan, Elvan. Black Is A Color - A History of African American Art. Dijon: Les Presses du réel, 2004.

\section{NOTES}

1. The video installation can be seen on the website of the Hammer Museum. https:// hammer.ucla.edu/take-it-or-leave-it/art/cornered <accessed on August 27, 2021>

2. Maurice Berger, "The Critique of Pure Racism: An Interview with Adrian Piper," Afterimage 18, no. 3 (1990): 9.

3. Wallace Thurmond. The Blacker the Berry (New York: Macaulay, 1929), 10.

4. This paper however confines itself to Piper's career as an artist.

5. “News," Adrian Piper Research Archive. http://www.adrianpiper.com/news_sep_2012.shtml $<$ accessed on August 27, 2021>

6. An excerpt from a video of the performance can be found on the Adrian Piper Research Archive Foundation website: http://www.adrianpiper.com/vs/video_tmb.shtml <accessed on August 27, 2021>

7. She writes in the caption to Thwarted Projects, Dashed Hopes, A Moment of Embarrassment where she "retires from being black," "Dear Friends, For my 64th birthday, I have decided to change my racial and nationality designations. Henceforth, my new racial designation will be neither black nor white but rather $6.25 \%$ grey, honoring my 1/16th African heritage. And my new nationality designation will be not African American but rather Anglo-German American, reflecting my preponderantly English and German ancestry. Please join me in celebrating this exciting new adventure in pointless administrative precision and futile institutional control!" "News," Adrian Piper Research Archive. http://www.adrianpiper.com/news_sep_2012.shtml <accessed on August 27, 2021>

8. The Adrian Piper Research Archive Foundation website presents a letter written by Piper to the Dean of her philosophy department at Wellesley College where she explains her refusal to go back to the United States. "Notifies Wellesley College of SSSS List and Requests Indefinite Leae of absence," Adrian Piper Research Archive. http://www.adrianpiper.com/docs/IndefLvApplic.pdf $<$ accessed on August 27, 2021>

9. Piper, "Notes on Mythic Being I-III", Out of Order, Out of Sight: Volume 1 Selected Writings in metaArt, 1968-1992 (Cambridge, MA: MIT Press, 1999), 117.

10. Cherise Smith explores Piper's personas in relation to other contemporary artists's uses of disguise in Enacting Others: Politics of Identity in Eleanor Antin, Nikki S. Lee, Adrian Piper, and Anna Deavere Smith (Durham: Duke University Press, 2011). 
11. A reproduction of the artwork can be viewed on the website of the Hammer Museum. https:// hammer.ucla.edu/exhibitions/2018/adrian-piper-concepts-and-intuitions-1965-2016 <accessed on August 27, 2021>

12. Quoted in Uri McMillan, Embodied Avatars: Genealogies of Black Feminist Art and Performance (New York : NYU Press, 2015), 95.

13. https://hammer.ucla.edu/take-it-or-leave-it/artists/adrian-

piper\#: :text=The\%20video\%20installation\%20Cornered\%20(1988,I\%20am\%2C\%20you\%20become\%20antagonized $<$ accessed on August 27, 2021>

14. Piper, Out of Order, Out of Sight, Volume 1, 305.

15. Piper, Out of Order, Out of Sight, Volume 1, 293.

16. W. E. B. Du Bois, The Souls of Black Folk (New York: Dover, 1994), 9.

17. An extract from a video of one of her Funk Lessons can be viewed on the Adrian Piper Research Archive Foundation website. Funk Lessons, Adrian Piper Research Archive. http:// www.adrianpiper.com/vs/video_fl.html <accessed on August 27, 2021>

18. "Notes on Mythic Being I-III", Out of Order, Out of Sight: Volume 1. op. cit.

19. John P. Bowles, Adrian Piper: Race, Gender, and Embodiment (Durham, NC: North Carolina University Press, 2011), 2.

20. Uri McMillan, Embodied Avatars: Genealogies of Black Feminist Art and Performance (New York: NYU Press, 2015), 145.

21. Piper wrote a response to a review of a retrospective on her work organized by the New Museum in New York in 2000 written by the New York Times art critic Ken Johnson where she lists, among other arguments, the following points:

I do not want to "make people behave better."

I do not work to "force anyone into anything."

I do not view "the system" as "pervasively racist, xenophobic and unjust."

I do not "more or less tacitly" take the "art-world audience to be white and liberal."

I do not presume the viewers of Cornered to be white.

I do not make "attempts at psychological manipulation."

"Letter to the Editors of the New York Times," Adrian Piper Research Archive. http:// www.adrianpiper.com/ny_times.shtml <accessed on August 27, 2021>

22. Piper, Out of Order, Out of Sight, Volume 1,154.

23. Piper quoted in George Yancy ed., African-American Philosophers (New York and London: Routledge, 1998), 64.

24. "Letter to the Editors of the New York Times," Adrian Piper Research Archive. http:// www.adrianpiper.com/ny_times.shtml <accessed on August 27, 2021>

25. "News," Adrian Piper Research Archive. http://www.adrianpiper.com/news_sep_2012.shtml $<$ accessed on August 27, 2021>

26. Piper, Out of Order, Out of Sight, Voume 1, xix.

27. Bowles, Adrian Piper: Race, Gender, and Embodiment, 208.

28. Adrian Piper, Escape to Berlin (APRA: Berlin, 2018), 4.

29. Piper, Out of Order, Out of Sight, Volume 1, xxxvii.

30. Adrian Piper quoted in Lucy Lippard, Six Years: The Dematerialization of the Art Object from 1966 to 1972 (New York: Praeger, 1973), 168.

31. She explains, "In the Spring of 1970 a number of events occurred that changed everything for me: (1) the invasion of Cambodia; (2) the Women's Movement; (3) Kent State and Jackson State; (4) the closing of CCNY [City College of New York], where I was in my first term as a philosophy major, during the student rebellion," Bowles, Adrian Piper, 125.

32. She explains: "Adrian Piper does not permit or approve the inclusion of her work in racially segregated exhibitions." "Art," Adrian Piper Research Archive. http://adrianpiper.org/art/ index.shtml <accessed on August 27, 2021> 
33. Adrian Piper, "Some Thought on the Political Character of This Situation" in Alberro, Alexander and Blake Stimson, eds. Institutional Critique: An Anthology of Artists' Writings (Boston, MA: MIT Press, 2009), 243.

34. Jacqueline Royster and Ann Marie Mann Simpkins, eds. Calling Cards: Theory and Practice in the Study of Race, Gender and Culture (Albany, NY: SUNY Press, 2012), ix.

35. A reproduction of the calling card can be viewed on the Yale Art Gallery website. "My calling (card \#1)," Yale University Art Gallery. https://artgallery.yale.edu/collections/objects/218575 <accessed on August 27, 2021>

36. Gyatri Spivak, "Subaltern Studies: Deconstructing Historiography," in Selected Subaltern Studies, eds. Ranajit Guha and Gyatri Chakravorty Spivak (New York: Oxford University Press, 1988), 11-12.

37. This video opens the website to the MoMA exhibition of Piper's work. "Adrian Piper: A Synthesis of Intuitions, 1965-2016," MoMA. https://www.moma.org/calendar/exhibitions/3924 $<$ accessed on August $27^{\text {th }}, 2021>$

38. Ralph Waldo Ellison, Collected Essays, John F. Callahan ed. (New York: Modern Library, 2003), 243.

39. Ellison, Collected Essays, 257.

40. Piper, Out of Order, Out of Sight, Volume 1, xix.

41. Allan Kaprow, The Blurring of Art and Life (Berkeley, CA: University of California Press, 1993.

42. John Dewey, Art as Experience (New York: Penguin, 2005), 2.

43. John Dewey, "The Need for a Recovery of Philosophy," in Pragmatism, eds. Kerry J. Noble, Cheryl Misak (Calgary: University of Calgary Press, 1999), 131.

44. Dewey, Art as Experience, 35.

45. Adrian Piper, Out of Order, Out of Sight, Volume 1, 248.

46. A photograph of the installation can be seen on the Adrian Piper Research Archive Foundation website. "The Probable Trust Registry," The Adrian Piper Research Archive. http:// www.adrianpiper.com/art/The_Probable_Trust_Registry.shtml <accessed on August 27, 2021>

47. The contract to be signed by viewers can be read on the Adrian Piper Research Archive Foundation website: “TPTR Generalized Performance Instructions Website," The Adrian Piper Research Archive. http://www.adrianpiper.com/art/docs/ TPTRGeneralizedPerformanceInstructionsWebsite.pdf < accessed on August 27, 2021>

\section{ABSTRACTS}

Adrian Piper's career which spans close to 60 years illustrates the passage in American art from conceptualism to performance art at the turn of the 1970s. She uses the language of conceptualism to interrogate, through performance, the notion of identity in American culture. Confronting her viewers with racial stereotypes, or presenting strategies of retreat, her performances suggest that identity is a fluctuating notion, one which can only exist in dialogue between artist and audience. Her critique of essentialism is at the heart of artworks which are to be construed as social contracts binding artist and audiences together in the definition of the self. 
INDEX

Keywords: Adrian Piper, conceptualism, performance, institutional critique, African-American art

\section{AUTHOR}

\section{ANTONIA RIGAUD}

Antonia Rigaud is Associate Professor of American Studies at Sorbonne Nouvelle University. Her research focuses on experimental literature and art in the United States in the $20^{\text {th }}$ and $21^{\text {st }}$ centuries. She has published a book on the art of John Cage (John Cage Théoricien de l'utopie. Paris: Harmattan, 2006), and articles on American poetry, visual arts and performance. Her current research focuses on the meeting points between art and politics in the American avantgarde. 